\title{
Morphological evaluation of the active tip of six types of orthodontic mini-implants
}

\author{
Flávia Mitiko Fernandes Kitahara-Céia ${ }^{1}$, Tatiana Féres Assad-Loss², José Nelson Mucha³, Carlos Nelson Elias ${ }^{4}$
}

Objective: To morphologically evaluate the active tip of six different types of self-drilling mini-implants for orthodontic anchorage. Methods: Images of the active tips of the mini-implants were obtained with a Zeiss optical microscope, Stemi 200-C with magnification of 1.6X. The images of the surface were viewed with the Axio Vision program (Zeiss, Jena, Germany) to calculate linear and angular measures. Mini-implant morphology and the details of tips and threads were also evaluated through Scanning Electronic Microscopy (SEM) (JEOL, model JSM5800 LV - JEOL, Tokyo, Japan) with magnifications of $90 \mathrm{X}$ and $70 \mathrm{X}$, respectively. The evaluation of the mini-implant taper shape was assessed using to the formula: $(b-a) /(2 \times D)$. Results: The following variables were measured: (1) active tip width, (2) major diameter of external thread, (3) minor diameter of internal thread and taper of the mini-implant, (4) number of threads and lead of the screw, (5) angle of thread, (6) flank width and (7) pitch width. Conclusion: Mini-implants from different manufacturers presented active tips with different characteristics. Mechanical testing is necessary to correlate the analyzed characteristics aiming to determine the best performance.

Keywords: Orthodontic anchorage procedures. Morphology. Orthodontics.

Objetivo: avaliar morfologicamente a ponta ativa de seis diferentes tipos de mini-implantes autoperfurantes para controle de ancoragem ortodôntica. Métodos: foram obtidas imagens das pontas ativas dos mini-implantes com o microscópio óptico Stemi 2000-C (Zeiss) com aumento de 1,6X. As imagens das superfícies foram analisadas no programa Axio Vision (Zeiss, Jena, Alemanha) para cálculo das medidas lineares e angulares. As morfologias dos mini-implantes e os detalhes das pontas e das roscas também foram avaliados por meio do Microscópio Eletrônico de Varredura (MEV) (JEOL, modelo JSM-5800 LV - JEOL, Tóquio, Japão) com aumentos de 90X e 70X, respectivamente. A avaliação da conicidade do mini-implante foi calculada de acordo com a fórmula: $(b-a)$ / (2 x D). Resultados: foram medidos (1) comprimento da ponta ativa, (2) diâmetro externo, (3) alma e conicidade do mini-implante, (4) número e passo das roscas, (5) ângulo do filete da rosca, (6) comprimento do flanco da rosca e (7) comprimento do fundo do filete da rosca. Conclusões: mini-implantes de diferentes fabricantes apresentaram suas pontas ativas com características diversas. Ensaios mecânicos são necessários para correlacionar as características analisadas

Palavras-chave: Procedimentos de ancoragem ortodôntica. Morfologia. Ortodontia.

${ }^{1} \mathrm{MSc}$ in Orthodontics and Specialist in Orthodontics, UFF, Niterói, RJ.

${ }^{2}$ Specialist in Orthodontics and MSc in Dentistry, UFF.

${ }^{3}$ Full professor of Orthodontics, UFF.

${ }^{4}$ Professor, Military Institute of Engineering - Rio de Janeiro, RJ.
How to cite this article: Kitahara-Céia FMF, Assad-Loss TF, Mucha JN, Elias $\mathrm{CN}$. Morphological evaluation of the active tip of six types of orthodontic miniimplants. Dental Press J Orthod. 2013 Mar-Apr;18(2):36-41.

Submitted: March 24, 2009 - Revised and accepted: June 29, 2009

» The author reports no commercial, proprietary or financial interest in the products or companies described in this article.

Contact address: Flávia Mitiko Fernandes Kitahara-Céia Rua General Andrade Neves, 275/1503 - São Domingos, Niterói / RJ, Brazil CEP: 24.210-001 -E-mail: flaviamitiko@yahoo.com.br 


\section{INTRODUCTION}

Anchorage control is a decisive factor for the success of determined orthodontic treatments and for this reason, efforts have been made to develop appropriate anchorage methods. All intraoral appliances show some anchorage loss and extraoral appliances depend on patient cooperation. ${ }^{22}$ The mini-implants introduced new possibilities of effective anchorage in orthodontics. ${ }^{15,16}$ The installation of the mini-implant is relatively simple and, due to its reduced size, it presents possibility of insertion in several sites such as palate, retromolar area, maxillary tuberosity and between the roots on the cortical bone of the posterior and anterior regions, both by lingual or buccal. ${ }^{6,711,12,16,22}$ Loading of the mini-implant can be performed immediately after installation, because retention is mostly mechanical. ${ }^{5,8}$ Primary stability is intrinsically related to bone support, design and type of insertion of the mini-implant. ${ }^{25}$ Mini-implants present three distinct parts: 1) the head, for installation of elastics, wires or NiTi springs; 2) Transmucosal profile or neck, region between the head and the screwable portion of the mini-implant responsible for maintenance of the health of peri-implant tissues; and 3) body or active tip of the mini-implant, which is inserted into the bone. ${ }^{19,24}$ Mini-implant shape must offer mechanical anchorage by the contact area between implant and bone, allowing force distribution without damaging bone tissue physiology. The design must also limit surgical trauma at the moment of insertion and allow a good primary stability. ${ }^{4}$ The cone-shaped screw assures the effect of bone condensation, improving quality and preventing from unwanted destruction of cortical bone, caused by eccentric insertion or change of axis during insertion, in other words, implant stability is not very affected by the ability of the operator or the insertion area. ${ }^{23}$ Mini-implants vary with the most different characteristics such as diameter, width, quantity and angulation of threads and a conical or cylindrical profile. ${ }^{9}$ Under microscopic observation, these differences are found mainly in relation to the number and proximity of the screw threads. ${ }^{20}$ Possibly, more threads enhance resistance to displacement and primary stability. ${ }^{1,24}$ The shape of the mini-implant must be considered when evaluating the mechanical resistance of this device, ${ }^{20}$ as well as the available space in the insertion area and the choice of the mini-implant diameter. Smaller diameter of the screws makes the insertion between the roots easier, reducing the risk of root contact ${ }^{17}$ and providing a reduced insertion torque..$^{13}$ The use of mini-implants with a diameter that is too large, in order to obtain a greater bone contact may cause risk of microfracture of the bone inside the threads and obstruction of the circulation, that may induce bone necrosis. On the other hand, a mini-implant with a diameter that is too small may fracture because of the friction with the bone, especially in the mandible. ${ }^{10}$ When there is cortical bone enough to stabilize the mini-implant, $1.5 \mathrm{~mm}$ in diameter is enough for both maxilla and mandible. ${ }^{18}$ To prevent injuries to the root of the adjacent teeth, the tip of the screwable portion must be narrow, facilitating the insertion and minimizing surgical trauma. ${ }^{23}$ Depending on bone quality of the area, the ideal combination of type, diameter and width of the mini-implant indicates the site to be used..$^{25}$ The conic screws present the higher values of insertion torque, however no correlation was found between mini-implant design and the pullout force..$^{13}$ The reduced dimensions increase the possibility of deformation of the mini-implant during its use or fracture at the moment of insertion or removal, which may be related to excessive pressure applied to the manual driver or to the use of the handpiece with torque superior to $10 \mathrm{Ncm} .{ }^{3,14,16}$ The use of orthodontic mini-implants is increasing in clinical practice, because of controlled tooth movement in cases of difficult solution, however, they are offered with different physical characteristics as reasons given by the manufacturers for best clinical performance. The purpose of this work was to morphologically evaluate six different types of selfdrilling mini-implants available in the market, analyzing the following characteristics: 1) active tip width, 2) major diameter of external thread, 3) minor diameter of internal thread and taper of the mini-implant, 4) number of threads and lead of the screw, 5) angle of thread, 6) flank width and 7) pitch width.

\section{MATERIAL AND METHODS}

Orthodontic self-drilling mini-implants from six different manufacturers with similar dimensional characteristics were used according to Table 1.

\section{Mini-implant morphology evaluation}

The morphology of the active part of the mini-implants was evaluated and identified by an observer calibrated and trained, by means of images obtained through 
the Zeiss optical microscope, Stemi 2000-C (Zeiss, Jena, Germany) with magnification of 1.6X. The surface images were analyzed with the Axio vision program (Zeiss, Jena, Germany) to calculate the linear and angular measures (Figs 1 and 2). The mini-implant morphology and the details of the tips and of the mini-implant were evaluated through a scanning electronical microscope (SEM) (JEOL, model JSM-5800 LV - JEOL, Tokyo, Japan) with magnification of $90 \mathrm{X}$ and $70 \mathrm{X}$ respectively. The evaluation of the mini-implant taper was calculated according to the formula: $(b-a) /(2 \times D)=$ mini-implant taper (Fig 3). The mini-implant shank is considered as its external diameter excluding the thread width.

\section{RESULTS}

The linear $(\mu \mathrm{m})$ and angular (degrees) measures of a mini-implant from each group are displayed on Table 2. The measures that present increasing relation from the neck to tip are shown in italic. The measure corresponding to the lead, angle of thread, flank width and pitch width correspond to mean value.

The images obtained on the SEM of the mini-implant, the details of the screw and the tip of the six types of mini-implants are displayed on Figures 4, 5 and 6.

\section{DISCUSSION}

The anchorage mechanism of the mini-implants is based on mechanical retention of the metallic structure on the cortical and dense bone and not necessarily on the concept of osseointegration. The shape and width of the screws are fundamental for its fixation. ${ }^{2,5,8}$ More threads represents more resistance to displacement and greater primary stability. ${ }^{1,2}$ In this context, characteristics such as active tip width, major diameter of external thread, minor diameter of internal thread, number of threads, pitch, thread angle, flank width, pitch width, mini-implant taper and percentage of the internal diameter in relation

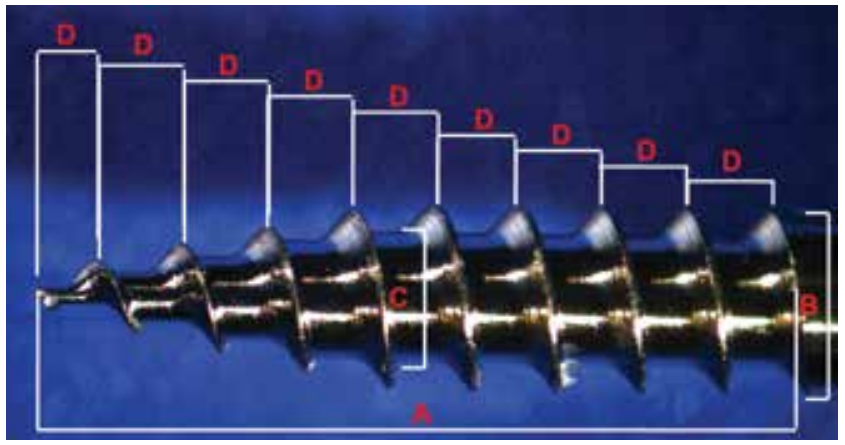

Figure 1 - A) Total width of the active tip; B) external diameter of the miniimplant; C) internal diameter of the mini-implant; D) number of threads and pitch of the screws.

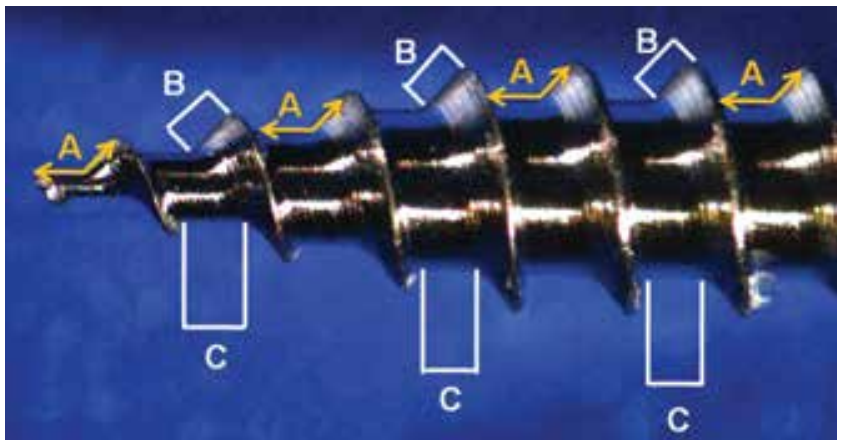

Figure 2 - A) Thread angle; B) flank width of the screw; C) pitch width.

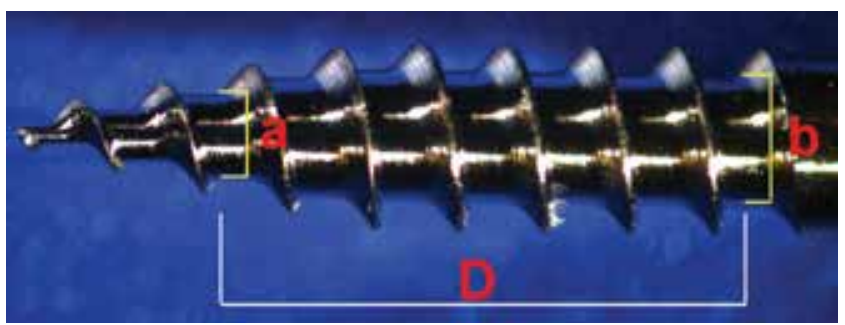

Figure 3 - Measurement of the mini-implant taper $=(b-a) /(2 \times D)$

Table 1 - Mini-implants used: Commercial name, manufacturer, origin, diameter, total width and transmucosal profile width according to information given by the manufacturer, as well as the acronym adopted in this study.

\begin{tabular}{|c|c|c|c|c|c|c|}
\hline Commercial Name & Manufacturer & Origin & Diameter & Width & Transmucosal prof. & Acronym \\
\hline Tomas & Dentaurum & Ispringen Germany & $1.6 \mathrm{~mm}$ & $6 \mathrm{~mm}$ & Not informed & DEN \\
\hline Dual-top Anchor System & Rocky Mountain Orthodontics & Korea & $1.6 \mathrm{~mm}$ & $6 \mathrm{~mm}$ & Not informed & $\mathrm{RMO}$ \\
\hline Orthoimplant & Conexão & Brazil & $1.5 \mathrm{~mm}$ & $6 \mathrm{~mm}$ & $1 \mathrm{~mm}$ & $\mathrm{CON}$ \\
\hline Implant for orthodontic anchorage & Neodent & Brazil & $1.6 \mathrm{~mm}$ & $7 \mathrm{~mm}$ & $1 \mathrm{~mm}$ & NEO \\
\hline Orthodontic screw Wire Dynamic & $\begin{array}{l}\text { SIN - Sistema de } \\
\text { Implantes Nacional }\end{array}$ & Brazil & $1.6 \mathrm{~mm}$ & $6 \mathrm{~mm}$ & $1 \mathrm{~mm}$ & SIN \\
\hline AbsoAnchor & Dentos & Korea & $1.6 \mathrm{~mm}$ & $6 \mathrm{~mm}$ & Not informed & ABS \\
\hline
\end{tabular}


Table 2 - Values of the linear and angular measures of the mini-implants for each group.

\begin{tabular}{|c|c|c|c|c|c|c|}
\hline \multirow{2}{*}{$\begin{array}{c}\text { EVALUATED } \\
\text { CHARACTERISTIC }\end{array}$} & \multicolumn{6}{|c|}{ MANUFACTURER } \\
\hline & DEN & RMO & CON & NEO & SIN & ABS \\
\hline Active tip width ( $\mu \mathrm{m})$ & 6006.01 & 5329.59 & 5926.47 & 6812.51 & 6090.93 & 5079.57 \\
\hline Major diameter of external thread $(\mu \mathrm{m})$ & 1607.96 & 1539.77 & 1482.95 & 1630.72 & 1562.59 & 1607.99 \\
\hline Minor diameter of internal thread ( $\mu \mathrm{m})$ & 1079.55 & 1028.42 & 772.75 & 1107.97 & 1164.77 & 1113.65 \\
\hline Number of threads $(\mu \mathrm{m})$ & 6 & 7 & 12 & 9 & 7 & 7 \\
\hline Pitch $(\mu \mathrm{m})$ & 888.09 & 735.39 & 464.49 & 732.32 & 756.49 & 688.31 \\
\hline Angle of thread (degrees) & 140.22 & 137.69 & 128.85 & 135.31 & 128.46 & 123.16 \\
\hline Flank ( $\mu \mathrm{m})$ & 381.96 & 384.78 & 232.11 & 360.58 & 292.79 & 399.5 \\
\hline Pitch width $(\mu \mathrm{m})$ & 395.63 & 327.65 & 239.77 & 323.86 & 376.89 & 327.65 \\
\hline Mini-implant taper & 0.11 & 0.07 & 0.09 & 0.10 & 0.10 & 0.09 \\
\hline $\begin{array}{l}\text { Percentage of the shank in } \\
\text { relation to external diameter }\end{array}$ & $67 \%$ & $67 \%$ & $52 \%$ & $68 \%$ & $75 \%$ & $69 \%$ \\
\hline
\end{tabular}

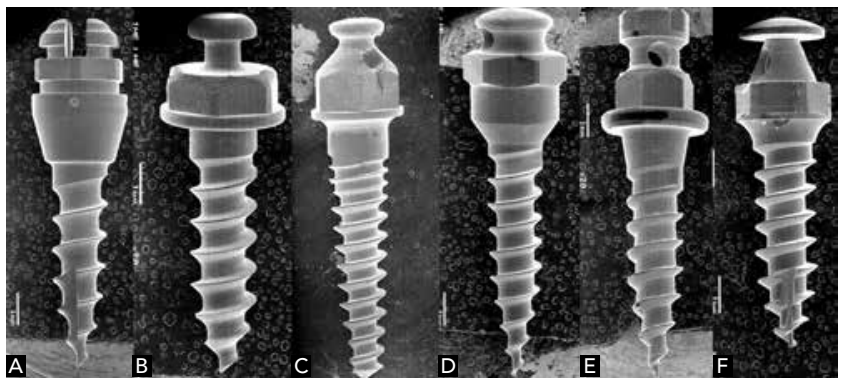

Figure 4 - Mini-implant morphology. A) Dentaurum; B) RMO; C) Conexão; D) Neodent; E) SIN; F) AbsoAnchor.
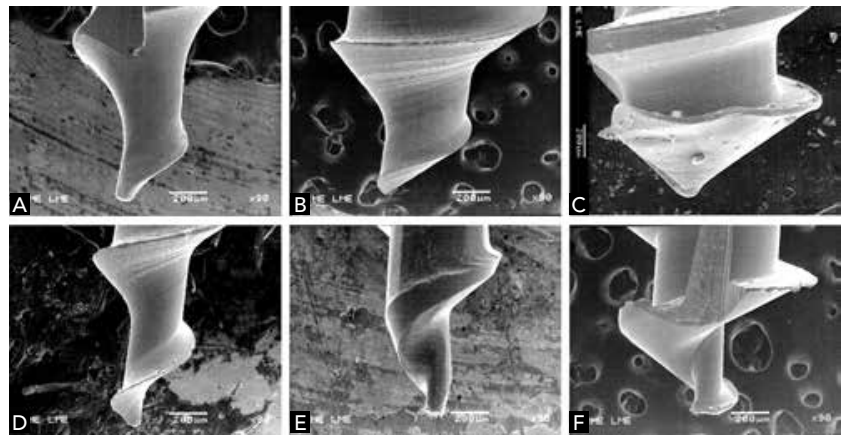

Figure 5 - Detail of the mini-implant tip, with magnification of $90 \mathrm{X}$ on the SEM. A) Dentaurum; B) RMO; C) Conexão; D) Neodent; E) SIN, F) AbsoAnchor.
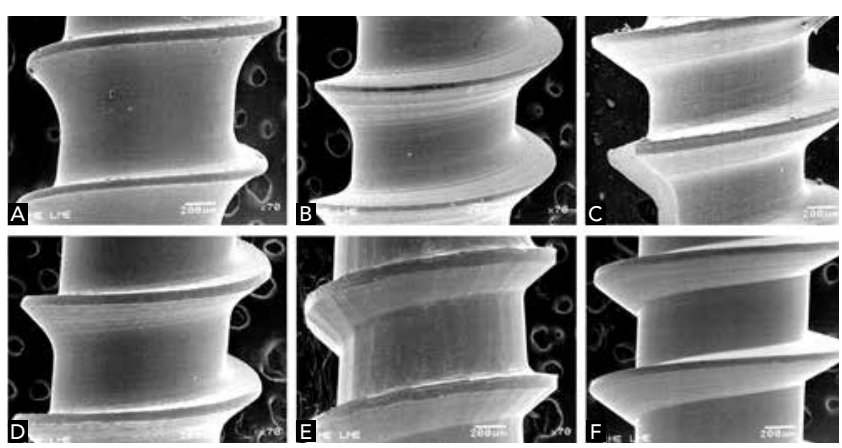

Figure 6 - Detail of the mini-implant thread, with magnification of $70 \mathrm{X}$ on the SEM A) Dentaurum; B) RMO; C) Conexão; D) Neodent; E) SIN, F) AbsoAnchor. to the external diameter, are related to the mechanical properties of the mini-implants especially retention and insertion torques.

\section{Active tip width}

In relation to the active tip width, the greatest difference observed, between the information given by the manufacturer (Table 1) and the data obtained in this study (Table 2) was with the mini-implants from RMO and AbsoAnchor, while the others presented widths correspondent or very close to those informed by the manufacturer.

\section{Mini-implant external diameter}

The reduced diameter of the mini implant is an important risk factor for fracture at the moment of insertion or removal. , $10,12,16,17$ On the other hand, miniimplants with a large diameter may cause bone necrosis due to microfractures. ${ }^{10}$ Mini-implants with a diameter smaller than $1.5 \mathrm{~mm}$ are more susceptible to fracture, ${ }^{17}$ with non-significant difference in the success rates when compared to mini-implants with diameter between 1.5 and $2.3 \mathrm{~mm} .{ }^{18}$ The diameter of the evaluated mini-implants ranged from $1482.95 \mu \mathrm{m}$ (Conexão) to $1630.72 \mu \mathrm{m}$ (Neodent).

\section{Minor diameter of internal thread}

The evaluation of the mini-implant minor diameter of internal thread is another relevant risk factor for fracture, small values could mean more susceptible areas. The diameter variation ranged from $772.75 \mu \mathrm{m}$ (Conexão) to $1164.77 \mu \mathrm{m}$ (SIN). 
Percentage of the minor diameter of internal thread in relation to external diameter

Regarding the correlation of the external diameter and the minor diameter of internal thread of the mini-implants, Conexão presented internal diameter of $52 \%$ of the total external diameter, meaning that the internal diameter is almost half the value of the external diameter.

\section{Number of threads}

A larger amount and reduced distance between the threads may lead to greater mechanical imbrication and, consequently, greater resistance to insertion of the miniimplant to the bone., 1,20,24 Among the evaluated mini-implants, the number of screws ranged from 6 (Dentaurum) to 12 (Conexão).

\section{Pitch}

The pitch represents the distance between the threads, being intimately related to the number of threads, more threads on the mini-implant, represent smaller distance between them. The mini-implant from Conexão presented the largest amount of threads, the distance between them was also smaller $(464.49 \mu \mathrm{m})$ and the mini-implant from Dentaurum presented the smallest amount of threads and a larger distance between them $(888.09 \mu \mathrm{m})$.

\section{Angle of thread}

With the measurement of the angle of thread, it can be considered that a smaller angle enables greater retention of the mini-implant. In the present study, the mini-implants that presented the smallest angle of thread were AbsoAnchor $\left(123.16^{\circ}\right)$, SIN $\left(128.46^{\circ}\right)$ and Conexão (128.85 $)$. However, reduced angles could complicate the insertion of the mini-implant, leading to high values of insertion torque, increasing the risk of fracture.

\section{Flank width}

By the evaluation of the flank width in the present study, it was possible to observe that the mini-implants from AbsoAnchor $(399.5 \mu \mathrm{m}), \mathrm{RMO}(384.78 \mu \mathrm{m})$ and Dentaurum $(381.96 \mu \mathrm{m})$ presented the highest mean with similar values, while those from Conexão (232.11 $\mu \mathrm{m})$ presented the lowest mean.

\section{Pitch width}

It is directly related to the pitch of the screw. Since the mini-implant from Dentaurum presented the largest distance between the threads, it also presented the largest pitch width $(395.63 \mu \mathrm{m})$ and those from Conexão the smallest width $(239.77 \mu \mathrm{m})$, confirming the smaller distance between the threads.

\section{Mini-implant taper}

The design of the mini-implants was evaluated through the active tip taper. The mini-implant from Dentaurum presented the greatest taper (0.11), while the smallest taper (0.07) was found in the mini-implant from RMO. The others ranged from 0.09 to 0.10 . The resistance to fracture can be increased with the conic design and with appropriate screws for self-drilling. ${ }^{2}$ For Kwok et $\mathrm{al},{ }^{13}$ conic screws present the highest values of insertion torque, although there is no correlation between the design of the mini-implant and the pullout strength. Tests of fracture to torsion and insertion torque are necessary to correlate morphological data such as diameter of the internal thread and taper of the mini-implant to the mechanical performance, assisting the clinician on the choice of the miniimplant with the morphological characteristics that most suits the clinical needs. It can be noticed from the present study that the mini-implants available on the market present active tips with different characteristics. Since this part of the mini-implant is responsible for its retention and also the most susceptible area to fracture, laboratory researches with mechanical tests must evaluate the relation of these characteristics to a better mechanical performance of the mini-implants. In this manner it will be possible to know the fundamental characteristics for the active tip of the mini-implant that allows a safe use of such devices.

\section{CONCLUSION}

Mini-implants from different manufacturers presented active tips with different characteristics.

The acquaintance of the ideal characteristics of mini-implant morphology will allow the conscious and substantiated choice for its use in several clinical application for orthodontic treatment.

Laboratory mechanical testing of insertion, removal, pullout and fracture are necessary to correlate the analyzed characteristics with the purpose of determining the best performance. 


\section{REFERENCES}

1. Araújo TM, Nascimento MHA, Bezerra F, Sobral M. C. Ancoragem esquelética em Ortodontia com mini-implantes. Rev Dental Press Ortod Ortop Facial. 2006;11(4):126-56.

2. Consolaro A, Sant Anna E, Francischone Jr CE, Consolaro MFM, Barbosa BA. Mini-implantes: pontos consensuais e questionamentos sobre o seu uso clínico. Rev Clín Ortod Dental Press. 2008;13(5):49-56.

3. Elias CN, Guimarães GS, Muller CA. Torque de inserção e de remoção de miniparafusos ortodônticos. Rev Bras Implant. 2005;11(3):5-8.

4. Favero L, Brollo P, Bressan E. Orthodontic anchorage with specific fixtures: Related study analysis. Am J Orthod Dentofacial Orthop. 2002;122(1):84-94

5. Freire JN, Silva NR, Gil JN, Magini RS, Coelho PG. Histomorphologic and histomophometric evaluation of immediately and early loaded miniimplants for orthodontic anchorage. Am J Orthod Dentofacial Orthop. 2007:131(6):704.e1-9.

6. Gelgor IE, Karaman Al, Buyukyilmaz T. Comparison of 2 distalization systems supported by intraosseous screws. Am J Orthod Dentofacial Orthop. 2007:131(2):161.e1-8.

7. Giancotti A, Arcuri C, Barlattani A. Treatment of ectopic mandibular second molar with titanium miniscrews. Am J Orthod Dentofacial Orthop. 2004;126(1):113-7

8. Herman RJ, Currier GF, Miyakec A. Mini-implant anchorage for maxillary canine retraction: a pilot study. Am J Orthod Dentofacial Orthop. 2006:130(2):228-35

9. Kanomi R. Mini-implant for orthodontic anchorage. J Clin Orthod. 1997 Nov:31(11):763-7.

10. Kim JH, Ahn SJ, Chang YI. Histomorfometric and mechanical analyses of the drill-free screw as orthodontic anchorage. Am J Orthod Dentofacial Orthop. 2005:128(2):190-4

11. Kuroda S, Sugawara Y, Tamamura N, Takano-Yamamoto T. Anterior open bite with temporomandibular disorder treated with titanium screw anchorage: evaluation of morphological and functional improvement. Am J Orthod Dentofacial Orthop. 2007:131(4):550-60.

12. Kuroda S, Yanagita T, Kyung HM, Takano-Yamamoto T. Titanium screw anchorage for traction of many impacted teeth in a patient with cleidocranial dysplasia. Am J Orthod Dentofacial Orthop. 2007:131(5):666-9.

13. Kwok AWL, Finkelstein JA, Woodside T, Hearn TC, Hu RW. Insertional torque and pull-out strengths of conical and cylindrical pedicle screws in cadaveric bone. Spine. 1996:21(1):2429-34.
14. Kyung HM, Park HS, Bae SM, Sung JH, Kim IB. Development of orthodontic micro-implants for intraoral anchorage. J Clin Orthod. 2003;37(6):321-8.

15. Mah J, Bergstrand F. Temporary anchorage devices: a status report. J Clin Orthod. 2005:39(3):132-6.

16. Marassi C, Leal A, Herdy JL, Chianelli O, Sobreira D. O uso de miniimplantes como auxiliares do tratamento ortodôntico. Ortodontia SPO. 2005:38(3):256-65

17. Melsen B, Verna C. Miniscrew implants: the Aarhus anchorage system. Semin Orthod. 2005:11(1):24-31

18. Miyawaki S, Koyama I, Inoue M, Mishima K, Sugahara T, Takano-Yamamoto T. Factors associated with the stability of titanium screws placed in the posterior region for orthodontic anchorage. Am J Orthod Dentofacial Orthop. 2003:124(4):373-8

19. Nascimento MHA, Araújo TM, Bezerra F. Microparafuso ortodôntico: instalação e protocolo de higiene periimplantar. Rev Clín Ortod Dental Press. 2006;5(1):24-43

20. Nova MFP, Carvalho FR, Elias CN, Artese F. Avaliação do torque de inserção, remoção e fratura de diferentes mini-implantes ortodônticos. Rev Clín Ortod Dental Press. 2008;13(5):76-87.

21. Park $\mathrm{H}$, Jeong $\mathrm{S}, \mathrm{K}$ won $\mathrm{O}$. Factors affecting the clinical success of screw implants used as orthodontic anchorage. Am J Orthod Dentofacial Orthop. 2006:130(1):18-25

22. Park YC, Choi YJ, Choi NC, Lee JS. Esthetic segmental retraction of maxillary anterior teeth with a palatal appliance and orthodontic mini-implants. Am J Orthod Dentofacial Orthop. 2007:131(4):537-44.

23. Squeff LR, Simonson MBA, Elias CN, Nojima LI. Caracterização de miniimplantes utilizados na ancoragem ortodôntica. Rev Clín Ortod Dental Press. 2008:13(5):49-56

24. Vilella H, Bezerra F, Laboissière M Jr. Microparafuso ortodôntico de titânio auto-perfurante (MPO): novo protocolo cirúrgico e atuas perspectivas clínicas. Innov Implant J. 2006:1(1):46-53.

25. Wilmes B, Rademacher C, Olthoff G, Drescher D. Parameters affecting primary stability of orthodontic mini-implants. J Orofac Orthop. 2006;67(3):162-74 